\title{
Performance and Analysis of Indirect Torque Control-Based Three-Phase Induction Motor
}

\author{
Andri Pradipta $^{1 *)}$, Santi Triwijaya ${ }^{2)}$, and Mohamad Ridwan ${ }^{3)}$ \\ 1,2) Politeknik Perkeretaapian Indonesia Madiun, Indonesia \\ ${ }^{3)}$ Dept. of Electrical Engineering, Politeknik Elektronika Negeri Surabaya, Indonesia \\ Corresponding Email: *) andri@ppi.ac.id
}

\begin{abstract}
Induction motors are widely used in industrial processes, vehicles and automation. Three-phase induction motors can be used for traction systems on electric locomotives. In this case, the speed control system is an important thing that must be applied to the propulsion system. This study aimed to test the indirect torque control for a Three-phase induction motor. A proportional integral (PI) controller was applied for speed controller. The indirect torque control system was modeled and simulated using PSIM software. According to the result, the control method showed a good performance. The speed could be maintained even the speed reference was changing or a load was applied. The steady state error of the speed response was just $0.1 \%$ with rise time around $0.06 \mathrm{~s}$. The stator current went up to 39.5 A in starting condition. The stator current reached 12 A rms when the load of $10 \mathrm{Nm}$ was applied. Then, the current rose to $15.7 \mathrm{~A}$ rms when the load was increased to 40 $\mathrm{Nm}$ and the current came down to $12.8 \mathrm{~A}$ rms when the load was decreased to $20 \mathrm{Nm}$.
\end{abstract}

Keywords: performance, Three-phase induction motor, control, torque, speed.

\section{INTRODUCTION}

Three-phase induction motors have recently become popular in the control and automation industries. Due to its durability, ruggedness, and near-zero maintenance requirements, the induction motor is widely employed in industry. However, due to the complexity and nonlinearity of the motor model, the operating condition of induction motors is dependent on parameters that reduce performance and reliability [1]. Previous Research [2], [3] present several strategies for maintaining motor performance but not feasible for applications due to complicated implementation issues. For example in railway transportation sector, induction motor was applied on traction system for propulsion purposes [4]-[6]. A design of traction motor by PT. PINDAD for Jabodetabek electric train has smaller dimension with higher power compared to previous existing traction motor of Jabodetabek electric train [5].

Three-phase PWM approaches are used to manage the input voltage to the Three-phase induction motor. However, performance degrades in dynamic conditions such as starting, abrupt changes in load, and speed reversal [7]. In vector controlled approaches, the input voltage to the motor is adjusted so that the motor draws the needed amount of direct and quadrature axis currents to meet the requirements of desired speed and torque. The qualities of a separately excited dc motor are adopted by flux orientated methods induction motors, where speed and torque are controlled individually and there is no decoupling between the field and armature circuits [8].

It is critical to maintain a phase difference of 90 degrees between the stator direct axis current and the stator quadrature axis current, which are responsible for controlling speed and torque, in order to accomplish decoupling of speed and torque control. Therefore, a controllers is needed to keep the current values at the appropriate levels. However, due to the change in operating points under transient conditions, constructing an exact model and determining the machine's instantaneous parameters is not possible [9]. As a result, traditional strategies for controlling torque and speed, such as P controllers, PI controllers, and PID controllers, do not produce sufficient results.

In this study, indirect vector control method is used to maintain the speed of three-phase induction motor. PI controller is applied as the error compensator to got the value of $\mathrm{V}_{\mathrm{d}}$ and $\mathrm{V}_{\mathrm{q}}$ that will be transform into $\mathrm{V}_{\mathrm{abc}}$ as the sinusoidal pulse width modulation (SPWM) control reference, so the speed can be maintained. The following is a breakdown of the structure of this paper : An induction motor is mathematically modelled in Section 2. Section 3 explains the scheme of indirect vector control. Section 4 discusses the simulation results and analyses. The conclusion is given in the final part. With this research, it is hoped that it can be implemented in the form of a laboratory-scale prototype for validation of this system. so that later it can be used to speed controller of Three-phase induction motors used for traction systems on electric locomotives.

\section{INDUCTION MOTOR MODEL}

\section{A. Modelling of Induction Motor Model}

Dynamic modeling derivations of induction motors imply linearity of rotor and stator with Three-phase balance and symmetrical structure. Both the stator and rotor reference frames are often calculated in synchrony from equations of motion, voltage, and flux linkage [10]. 
As illustrated in Figure 1, the dq-axis of the equivalent model for induction motor is achieved by decoupling an real part and imaginary part from the space vector model with equations of voltage, motion, and flux linkage.

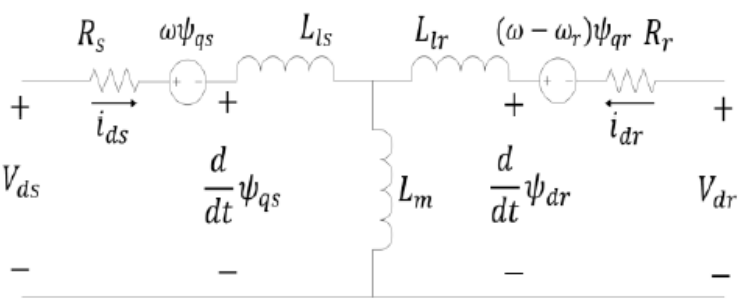

(a)

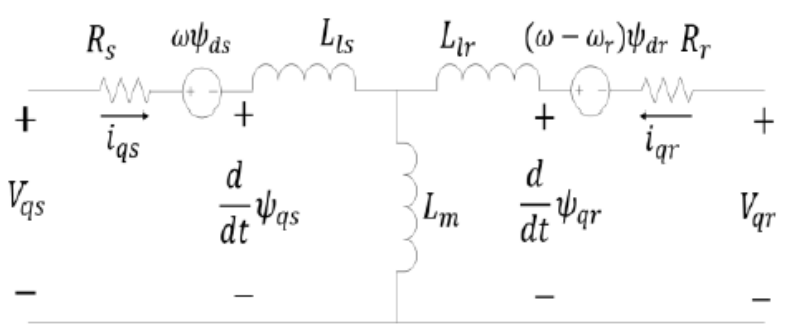

(b)

Figure 1. Eq. model; (a) d-axis, (b) q - axis of an induction motor

The voltage equations corresponding to the flux linkages in both the stator and rotor reference frames in the dq-axis are as follows:

$$
\begin{gathered}
V_{d s}=R_{s} I_{d s}+\frac{d \psi_{d s}}{d t}-\omega \psi_{q s} \\
V_{q s}=R_{s} I_{q s}+\frac{d \psi_{q s}}{d t}+\omega \psi_{d s} \\
V_{d r}=R_{r} I_{d r}+\frac{d \psi_{d r}}{d t}-\left(\omega-\omega_{r}\right) \psi_{q r} \\
V_{q r}=R_{r} I_{q r}+\frac{d \psi_{q r}}{d t}+\left(\omega-\omega_{r}\right) \psi_{d r}
\end{gathered}
$$

$V_{d r}, V_{q r}$ and $V_{d s}, V_{q s}$, refer to dq - axis voltage of the rotor and dq - axis of the stator, while $I_{d s}, I_{q s}$, and $I_{d r}, I_{q r}$ refer to $\mathrm{dq}$ - axis current of the stator and dq - axis current of the rotor respectively. Hence, the flux linkages of dqaxis stator and rotor are described as $\psi_{d s}, \psi_{q s}$, and $\psi_{d r}$, $\psi_{q r}$ respectively. The resistances of the stator and rotor are determined by $R_{s}$ and $R_{r}$. The rotational electrical speed and arbitrary reference frame for rotational speed are represented as $\omega, \omega_{r}$ respectively.

In terms of comparable equations, the flux linkage of the $\mathrm{dq}$ - axis is:

$$
\begin{aligned}
& \psi_{d s}=L_{s} I_{d s}+L_{m} I_{d r} \\
& \psi_{q s}=L_{s} I_{q s}+L_{m} I_{q r} \\
& \psi_{d r}=L_{r} I_{d r}+L_{m} I_{d s} \\
& \psi_{q r}=L_{r} I_{q r}+L_{m} I_{q s}
\end{aligned}
$$

Self - inductances of stator and rotor are represented as $L_{s}$ and $L_{r}$, while $L_{d r}$ and $L_{d s}$ show the leakage inductances of rotor and stator. $L_{m}$ is the magnetizing inductance where $L_{m}=L_{r}-L_{l r}$ or $L_{m}=L_{s}-L_{l s}$. If the equation number 5 to 8 is subtituted with equation number 1 to 4 , then, it become equation number 9 to 12 .

$$
\begin{gathered}
V_{d s}=R_{s} I_{d s}+L_{l s} \frac{d I_{d s}}{d t}+L_{m} \frac{d\left(I_{d s}+I_{d r}\right)}{d t}-\omega \psi_{q s} \\
V_{q s}=R_{s} I_{q s}+L_{l s} \frac{d I_{q s}}{d t}+L_{m} \frac{d\left(I_{q s}+I_{q r}\right)}{d t}+\omega \psi_{d s} \\
V_{d r}=R_{r} I_{d r}+L_{l r} \frac{d I_{d r}}{d t}+L_{m} \frac{d\left(I_{d s}+I_{d r}\right)}{d t}-\left(\omega-\omega_{r}\right) \psi_{q r} \\
V_{q r}=R_{r} I_{q r}+L_{l r} \frac{d I_{q r}}{d t}+L_{m} \frac{d\left(I_{q s}+I_{q r}\right)}{d t}+\left(\omega-\omega_{r}\right) \psi_{d r}
\end{gathered}
$$

Figure 1 depicts the above Eq.(9)-(12) for the dq-axis eq. model. The d-axis eq. model is shown in figure 1(a) and the q-axis equivalent model is shown in figure 1(b).

To demonstrate the equation of electromagnetic torque, the motion equation from the model of space vector is adjusted in several ways. It can be modeled by combine fluk linkage equation of stator and rotor with dq stator current. So, the electromagnetic torque equation is become below:

$$
T_{e}=\left\{\begin{array}{l}
\frac{3 P}{2}\left(I_{q s} \psi_{d s}-I_{d s} \psi_{q s}\right) \\
\frac{3 P L_{m}}{2}\left(I_{q s} I_{d r}-I_{d s} \psi_{q r}\right) \\
\frac{3 P L_{m}}{2 L_{r}}\left(I_{q s} \psi_{d r}-I_{d s} \psi_{q r}\right)
\end{array}\right.
$$

Finally, the equations of motion torque and electromagnetic torque to use in simulation are as follows:

$$
\begin{gathered}
\frac{d \omega_{m}}{d t}=\frac{P}{J}\left(T_{e}-T_{m}\right) \\
T_{e}=\frac{3 P}{2}\left(I_{q s} \psi_{d s}-I_{d s} \psi_{q s}\right)
\end{gathered}
$$

The mechanical speed of induction motor was represented with $\omega_{m}$. The mechanical and electrical torque are represented as $T_{m}$ and $T_{e}$, respectively, while $P$ is the number of poles.

\section{B. Indirect Torque Control Scheme}

The Scheme of Indirect vector control is similar to the scheme of vector control, with the exception that the unit vectors are generated in a feed - forward way. With the use of a phasor diagram, the essential idea of indirect vector control is illustrated in the diagram below. 


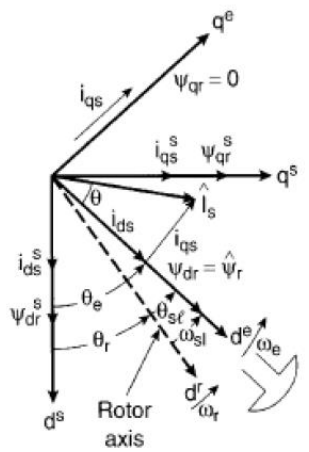

Figure 2. Indirect vector control phasor diagram

The equations used to implement the indirect vector control approach are as follows:

$$
\begin{gathered}
\theta_{s}=\int \omega_{e} d t=\int\left(\omega_{e}+\omega_{s t}\right) d t=\theta_{r}+\theta_{s l} \\
R_{r} I_{d r}+\frac{d \psi_{d r}}{d t}-\left(\omega_{e}-\omega_{r}\right) \psi_{q r}=0 \\
R_{r} I_{q r}+\frac{d \psi_{q r}}{d t}-\left(\omega_{e}-\omega_{r}\right) \psi_{d r}=0 \\
I_{d r}=\frac{1}{L_{r}} \psi_{d r}+\frac{L_{m}}{L_{r}} I_{d s} \\
I_{q r}=\frac{1}{L_{r}} \psi_{q r}+\frac{L_{m}}{L_{r}} I_{q s}
\end{gathered}
$$

The torque component of $I_{q s}$ is generated by the speed control loop, while the flux component of current $I_{d s}$ is calculated using the equations above. To satisfy the phasor diagram, the slip frequency $\omega_{s l}$ is created from $I_{q s}$ in a feed-forward manner using the equations above. The related slip gain $K_{S}$ expression is as follows:

$$
K_{s}=\frac{\omega_{s l}^{*}}{I_{q s}^{*}}=\frac{L_{m} R_{r}}{L_{r} \psi_{r}}
$$
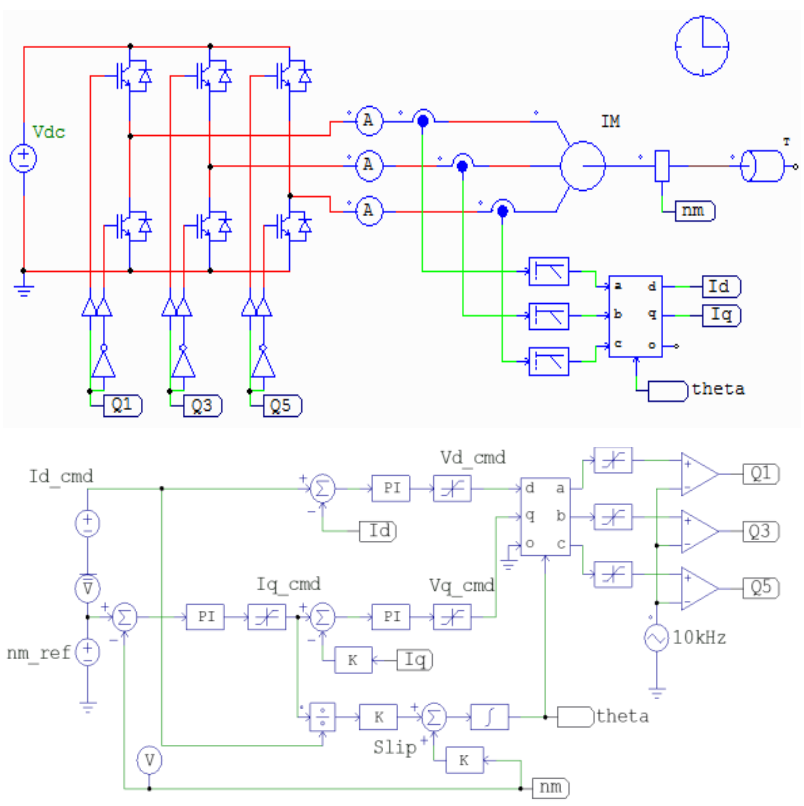

Figure 3. Simulation schematic diagram

\section{RESUlTS AND DISCUSSION}

The system is modelled and simulated using PSIM software. Figure 3 shows the simulation schematic diagram On PSIM. The simulation is done by observing the speed when the speed reference is set to a particular constant value. Then, it is tested by changing the speed reference, and the last is by changing the load with constant speed reference. The value of parameters used in this simulation are shown in Table 1 . The stator winding resistance is represented by $\mathrm{R}_{\mathrm{s}}$, in Ohm. The stator winding leakage inductance is represented by $\mathrm{L}_{\mathrm{s}}$, in $\mathrm{H}$. The rotor winding resistance referred to the stator side is represented by $\mathrm{R}_{\mathrm{r}}$, in Ohm. Rotor winding leakage inductance referred to the stator side is represented by $\mathrm{L}_{\mathrm{r}}$, in $\mathrm{H}$. The magnetizing inductance is represented by $\mathrm{L}_{m}$, in $\mathrm{H}$. The Number of poles is represented by P. Moment of Inertia Moment of inertia is represented by $\mathrm{J}$, in $\mathrm{kg}^{*} \mathrm{~m}^{2}$.

Table 1. Simulation parameters

\begin{tabular}{cc}
\hline Parameters & Value \\
\hline $\boldsymbol{R}_{\boldsymbol{s}}$ & $0.294 \Omega$ \\
\hline $\boldsymbol{L}_{\boldsymbol{s}}$ & $1.39 \mathrm{mH}$ \\
\hline $\boldsymbol{R}_{\boldsymbol{r}}$ & $0.156 \Omega$ \\
\hline $\boldsymbol{L}_{\boldsymbol{r}}$ & $0.74 \mathrm{mH}$ \\
\hline $\boldsymbol{L}_{\boldsymbol{m}}$ & $41 \mathrm{mH}$ \\
\hline $\boldsymbol{P}$ & 6 \\
\hline $\boldsymbol{J}$ & $0.002 \mathrm{~kg} \mathrm{~m}^{2}$ \\
\hline
\end{tabular}

\section{A. Constant Speed Reference}

A constant speed reference is tested to know the performance of the control method designed. The input DC Voltage with $500 \mathrm{~V}$ is applied on Three-phase inverter and a load with $10 \mathrm{Nm}$ is coupled on Three-phase induction motor operation. The speed reference is set to $1000 \mathrm{rpm}$, since the nominal speed of the motor used is $1000 \mathrm{rpm}$. Figure 4 shows the speed performance since $0 \mathrm{~s}$ to $1 \mathrm{~s}$. According to the result, the motor speed can reach the speed reference with steady state error of $0.1 \%$. When the motor is on starting condition, it occurs a transient speed response with rise time of $0.06 \mathrm{~s}$. When the speed has reached the speed reference, the oscillation occurs, but it happens just a moment with the maximum overshoot of speed reached $8.1 \%$.

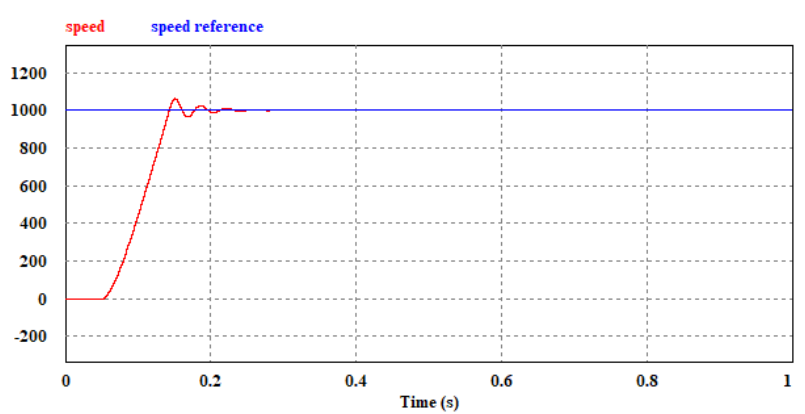

Figure 4. Speed response with constant speed reference 


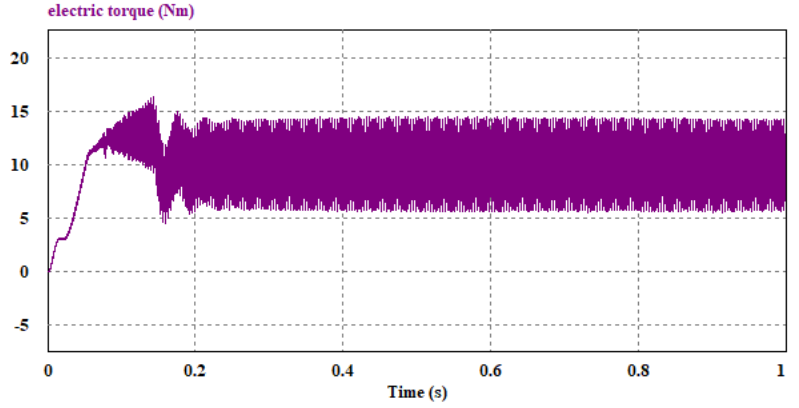

Figure 5. Electric torque response with constant speed reference is applied

Figure 5 shows the electric torque response with constant speed reference is applied. Figure 6 shows the stator line to line voltage. Stator line to line voltage is made from SPWM control method to drive Three-phase inverter. Figure 7 shows the stator current from start to $1 \mathrm{~s}$ when a constant speed reference is applied. According to the result, the maximum starting current reaches $39.5 \mathrm{~A}$. When the speed in a steady state condition, the stator current reaches steady condition as well and the electric torque reaches around $10 \mathrm{Nm}$ with $8 \mathrm{Nm}$ fluctuation. In this condition, the rms stator current reaches around 11.4 A (rms).

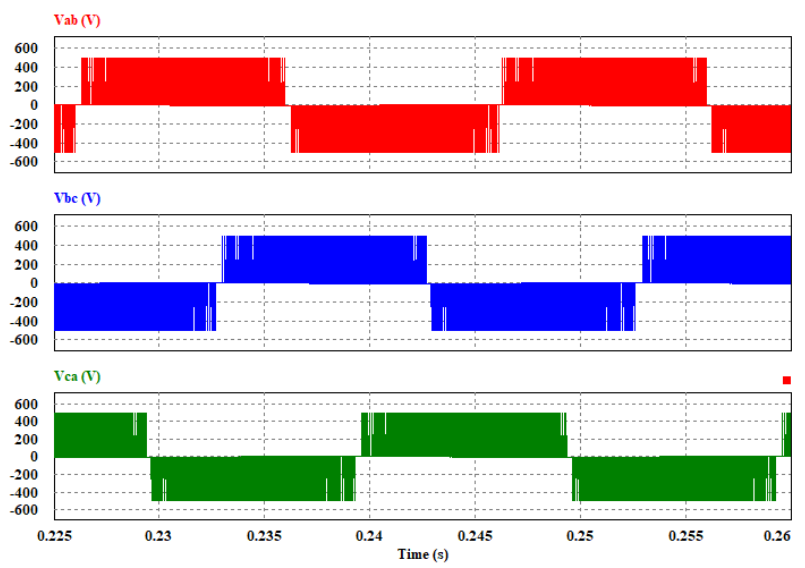

Figure 6. Stator Line to line voltage

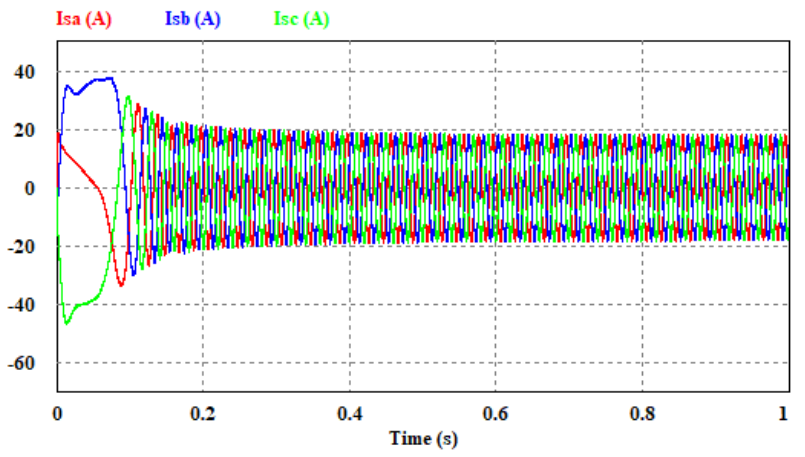

Figure 7. Stator current when a constant speed reference is applied

\section{B. Changing Speed Reference}

In the next testing, the reference of speed is set to be changing from 0 s to $2.5 \mathrm{~s}$. Firstly, the reference of speed is set to $1000 \mathrm{rpm}$ then, is set to $400 \mathrm{rpm}$ with the period of $0.8 \mathrm{~s}$. The last, the reference of speed is set to $750 \mathrm{rpm}$. Figure 7 shows the performance of control system method with the changing of speed reference. It is known that induction motor can reach the speed as the reference of speed is provided. When the speed reference is changing, motor experiences an oscillation in a short moment, with average period of $0.15 \mathrm{~s}$.

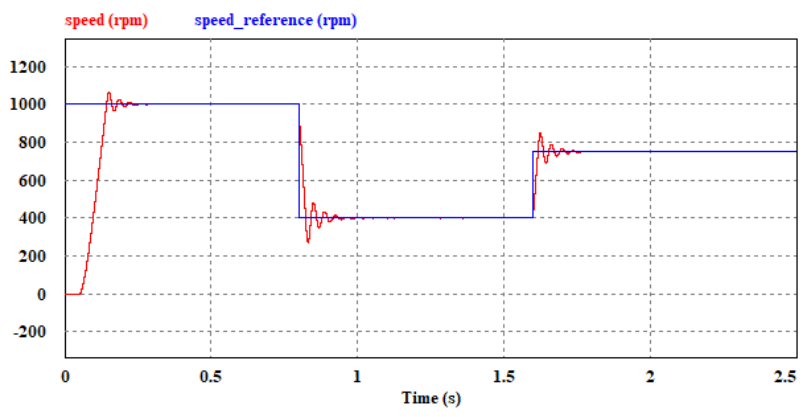

Figure 8. Speed response with changing speed reference

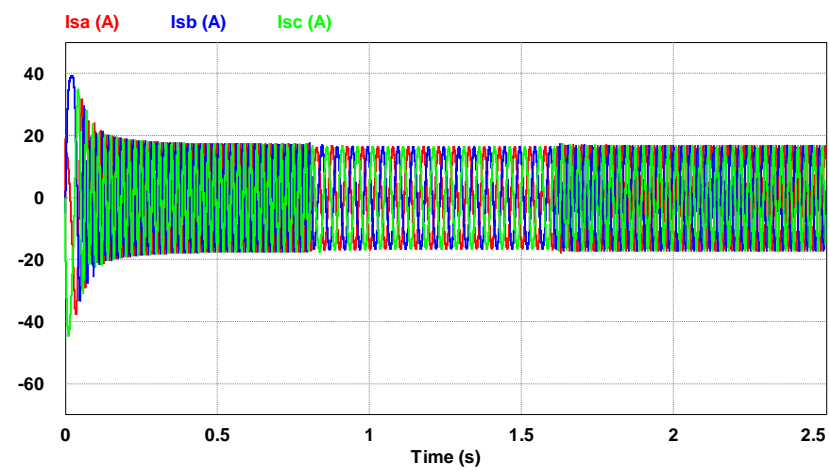

Figure 9. Stator current when a constant speed reference is changing

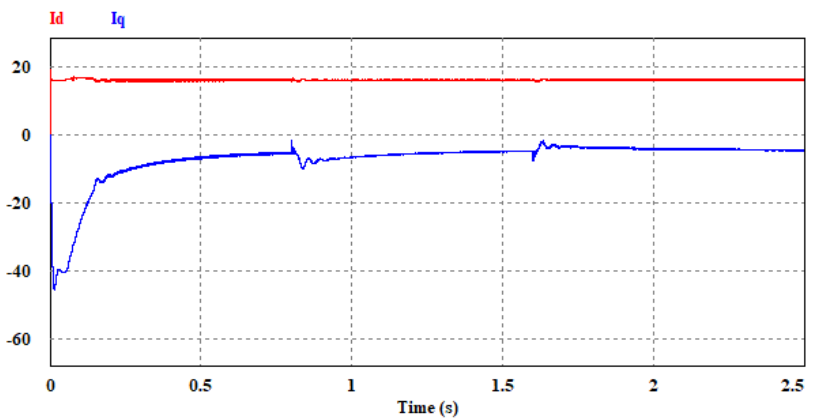

Figure 10. Stator current $\mathrm{I}_{\mathrm{a}, \mathrm{b}, \mathrm{c}}$ to $\mathrm{I}_{\mathrm{d}, \mathrm{q}}$ transformation

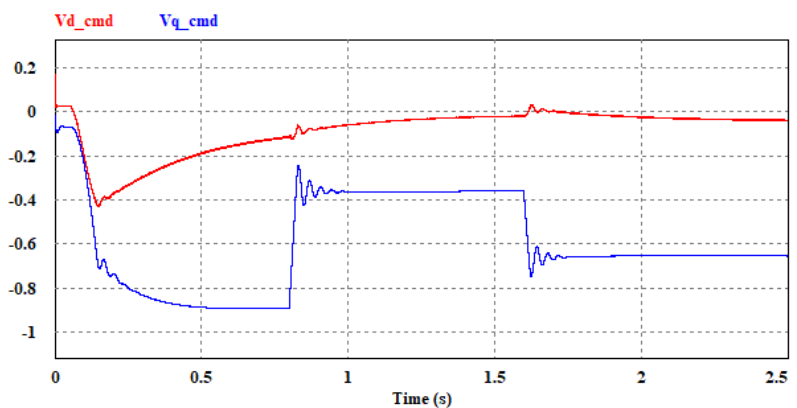

Figure 11. The Output signal $\mathrm{V}_{\mathrm{d}, \mathrm{q}}$ of PI controller as input of abc to dq transformation 

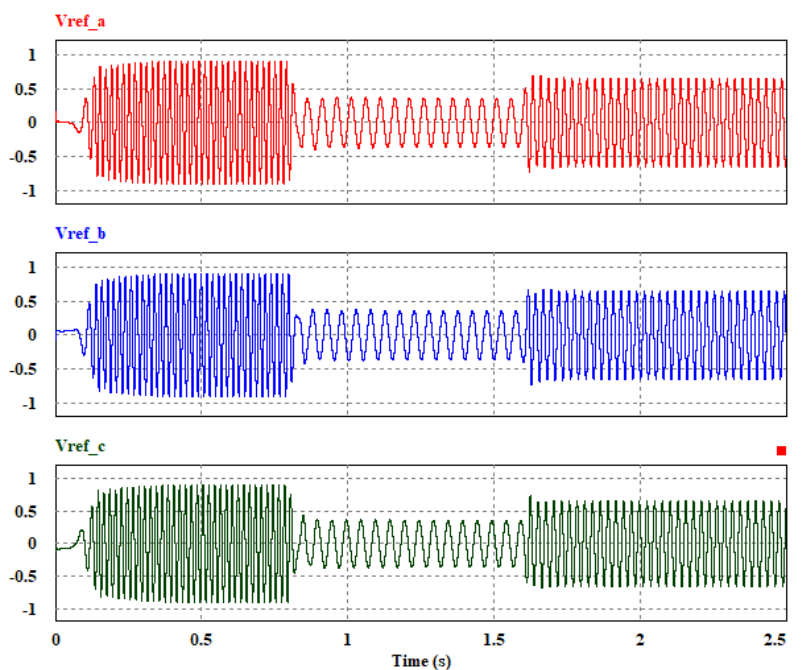

Figure 12. The input voltage reference $\left(\mathrm{V}_{\text {ref }}\right)$ of comparator to create the SPWM as inverter trigger signal

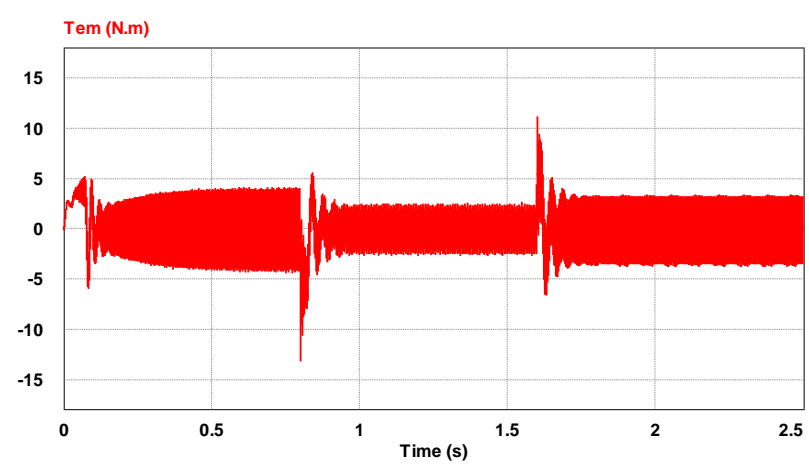

Figure 13. Torque when a constant speed reference is changing

Figure 13 shows the electromagnetic torque, respectively. The stator current shows no significant changes of amplitude value other than the frequency of the current wave when the speed reference is changing which is around 11.4 A. However, the frequency of stator current is highly different when the speed reference is changing. It depends on the speed. The faster the speed, the higher the stator current frequency. Moreover, the different torque ripple occurs when the speed is high or low. When the speed is slower, the electromagnetic torque ripple comes down as well.

Figure 9 shows Stator current $I_{a, b, c}$ to $I_{d, q}$ transformation. The stator current is measured and fed into the abc to dq transformation and the current is obtained in the d-axis and q-axis. This current will be fedback to the error compensator of PI controller to get the $V_{d}$ and $V_{q}$ signal that will be transformed first into $\mathrm{V}_{\mathrm{abc}}$ as the reference voltage for the SPWM signal generator. Figure 10 shows The Output signal $\mathrm{V}_{\mathrm{d}, \mathrm{q}}$ of PI controller as input of abc to dq transformation. Figure 11 shows The input voltage reference $\left(\mathrm{V}_{\text {ref }}\right)$ of comparator to create the SPWM signal as inverter trigger signal.

\section{Constant Speed Reference with Changing Load}

The next study is by applied a load which is changing in a particular time from $0 \mathrm{~s}$ to $2.5 \mathrm{~s}$. At $0 \mathrm{~s}$ to $0.8 \mathrm{~s}$, the load is set to 10 $\mathrm{Nm}$. At $0.8 \mathrm{~s}$ to $1.6 \mathrm{~s}$, the load is set to $40 \mathrm{Nm}$. At $1.6 \mathrm{~s}$ to $2.5 \mathrm{~s}$, the load is changed to $20 \mathrm{Nm}$. Figure 13 shows the load condition when it is applied to the system.

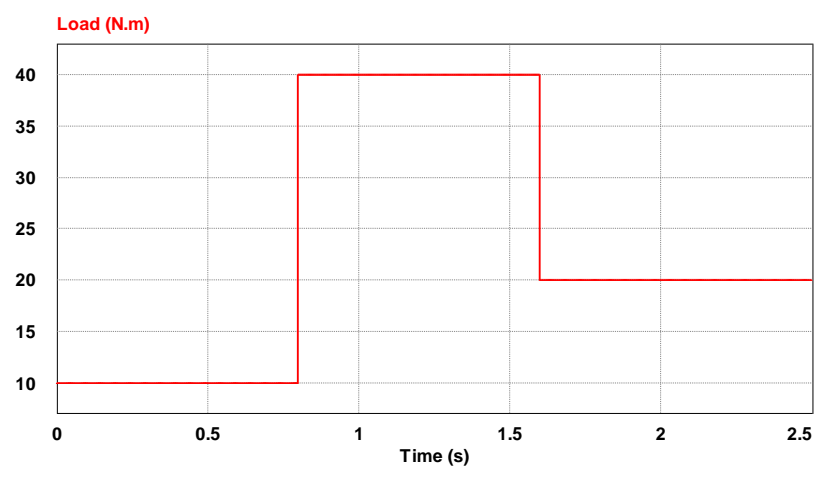

Figure 14. A load applied to the system

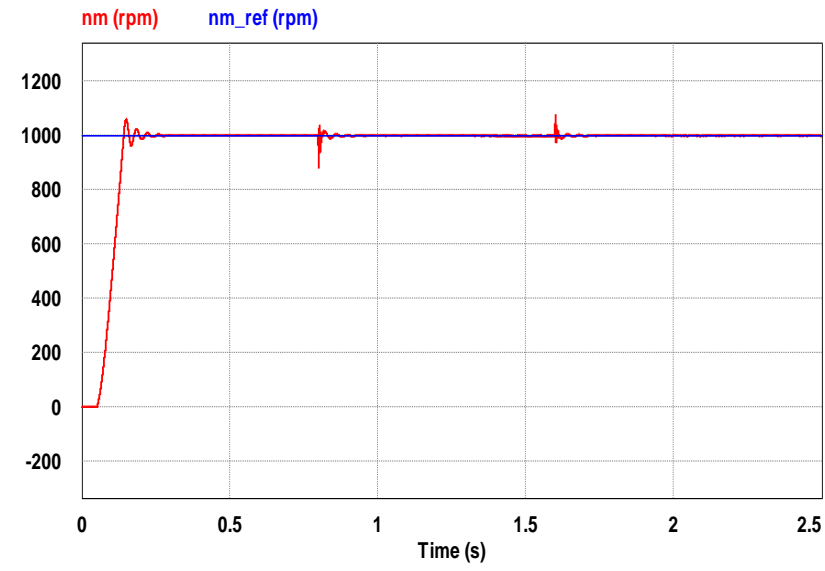

Figure 15. Speed response when a load changing is applied

Figure 15 shows the speed response from $0 \mathrm{~s}$ to $2.5 \mathrm{~s}$ when a load is applied to the system that shown in Figure 14. It is known that when the load is changing, there is a dip speed in a moment which is around $0.1 \mathrm{~s}$. Meanwhile, the speed can quickly recover to the reference value. Figures 16 and 17 show the electromagnetic torque when the load is applied and the stator current respectively. The result is the electromagnetic torque can keep up the reference load. When load is $40 \mathrm{Nm}$, the average electromagnetic torque is also $40 \mathrm{Nm}$. The stator current increases when the load is increased. The stator current reaches $12 \mathrm{~A} \mathrm{rms}$ when $10 \mathrm{Nm}$ load is applied. The current increases to 15.7 A rms when the load is increased to $40 \mathrm{Nm}$. Thereafter, the stator current decrease up to $12.8 \mathrm{~A}$ rms when the load is sag to $20 \mathrm{Nm}$.

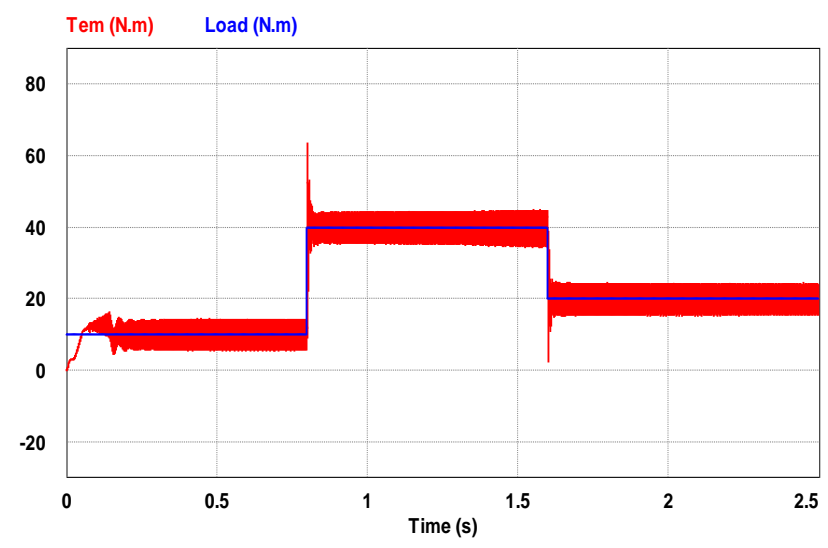

Figure 16. Electromagnetic torque when load is applied 


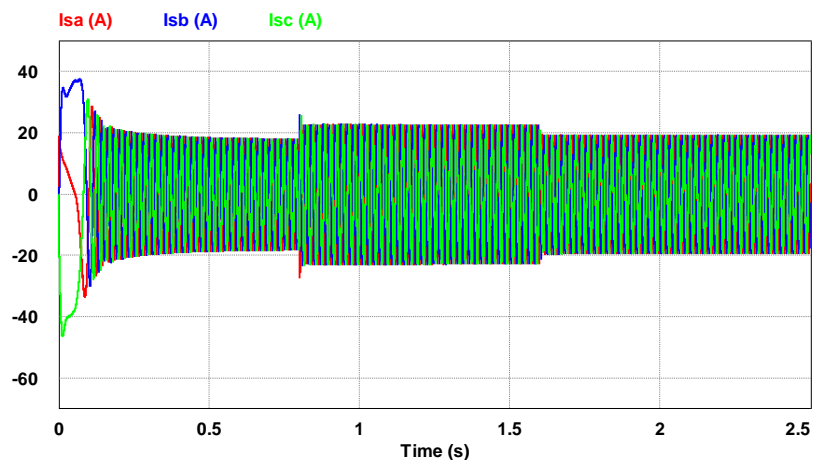

Figure 17. Stator current when load is applied

\section{CONCLUSION}

Indirect torque control for an induction motor has been studied. This method has worked and can control the speed of a Three-phase induction motor. The control method show a good performance. Speed response of the induction motor could follow the changing of speed reference with steady state error value is around $0.1 \%$ and rise time around $0.06 \mathrm{~s}$. The maximum stator current reached 39.5 $\mathrm{A}$ in transient condition. But, when it is in steady state condition, the current went down to $11.4 \mathrm{~A}$ rms. The system still showed good performance when both the speed reference was changing and a varied load was applied. When a varied load was applied, the motor could provide the electromagnetic torque as needed by the load. On the other hand, the speed response could still keep up to the speed reference. The stator current reached 12 A rms wen the load of $10 \mathrm{Nm}$ was applied. Then, the current rose to $15.7 \mathrm{~A}$ rms when the load was increased to $40 \mathrm{Nm}$ and the current came down to $12.8 \mathrm{~A} \mathrm{rms}$ when the load was decreased to $20 \mathrm{Nm}$

\section{REFERENCES}

[1] Y. Zhang and Z. Zhao, "Comparative study of PI, sliding mode and fuzzy logic controller for rotor field oriented controlled induction motor drives", International Conference on Electrical Machines and Systems 2008, Nov. 2008, pp. 1089 - 1094.

[2] K. Wang, et al., "An Online Rotor Time Constant Estimator for the Induction Machine," IEEE Trans. Control Syst. Technol., volume. 15, no. 2, pp. 339 - 348, Mar. 2007.

[3] D. Telford, et al., "Online identification of induction machine electrical parameters ...," IEEE Trans. Ind. Electron., volume. 50, no. 2, pp. 253 - 261, Apr. 2003.

[4] W. Song, et al., "One Cycle Control of induction machine traction drive for high speed railway part I : .., , in IECON 2010 - 36th Ann. Conf. on IEEE Industrial Electronics Society, Nov. 2010, pp. 2346 - 2351.

[5] A. Setiyoso, et al., "Design of traction motor 180kW type SCIM for KRL (EMU) Jabodetabek re-powering project," in 2014 International Conf. on Electrical Eng. and ... (ICEECS), Kuta, Bali, Indonesia, Nov. 2014, pp. $341-344$.

[6] S. Nategh et al., "A Review on different aspects of Traction Motor Design for Railway Applications," IEEE
Trans. Ind. Appl., volume. 56, no. 3, pp. 2148 - 2157, May 2020.

[7] C. Manes, et al., "DSP based field oriented control of induction motor with a nonlinear state observer," in PESC Record. 27th Annual IEEE Power Electronics Specialists Conf., Jun. 1996, vol. 2, pp. 1254 - 1259 vol.2.

[8] K.-K. Shyu, et al., "Adaptive field oriented control of induction motor with rotor flux observation," in 22nd International Conf. on Industrial Electr. ... IEEE IECON, Aug. 1996, volume. 2, pp. 1204 - 1209.

[9] H. Jun, et al., "A MRAS-based speed sensorless field oriented control of induction motor ...," in 1998 International Conf. on Power Electronic Drives and ..., 1998. Proceedings., Dec. 1998, volume. 1, pp. 38 - 43.

[10] K. Zeb, et al., "Indirect field - oriented control of induction motor drive based on adaptive fuzzy logic controller," Electr. Eng., volume. 99, Sep. 2017. 